\title{
Stand Regeneration Characteristics of Beech and Fir Forests in Gorski Kotar Region
}

\author{
Krunoslav Teslak ${ }^{1 *}$, Mislav Vedriš ${ }^{1}$, Marko Gašparović $^{1}$, Marijana Žunić ${ }^{1}$, Jura Čavlović ${ }^{1}$
}

(1) University of Zagreb, Faculty of Forestry, Department of Forest Inventory and Management, Svetošimunska 25, HR-10000 Zagreb, Croatia

* Correspondence: e-mail: kteslak@sumfak.hr

\begin{abstract}
Citation: TESLAK K, VEDRIŠ M, GAŠPAROVIĆ M, ŽUNIĆ M, ČAVLOVIĆ J Stand Regeneration Characteristics of Beech and Fir Forests in Gorski Kotar Region. South-east Eur for 7 (2): 99-108. DOI: https://doi. org/10.15177/seefor.16-15

Received: 6 Oct 2016; Revised: 15 Nov 2016; Accepted: 20 Nov 2016; Published online: 5 Dec 2016
\end{abstract}

\begin{abstract}
Background and Purpose: Beech-fir forests cover about 13\% of forest land in Croatia, thus being a significant forest resource that is dominantly managed by uneven-aged selection management system. Continuous and successful regeneration is an essential prerequisite for this kind of forest management. Therefore updated and sound information on the present state of regeneration is important, especially in the context of climate change and the actual structure of beech and fir forests. The aim of this paper is to present and analyse current state of regeneration in beech and silver fir forests of Gorski kotar region, with regard to forest ownership (management model), forest communities and habitat characteristics.

Materials and Methods: Field measurement has been done on 313 plots in the beech and fir forests of Gorski kotar region, Croatia. The assessment of regeneration was based on measurement of trees ranging from 0 to $10 \mathrm{~cm} d b h$ (species, number of trees, average height) and also the estimation of seedlings up to $1.30 \mathrm{~m}$ high (regenerated area in $10 \%$ classes, the share of tree species, the origin of stand establishment, regeneration quality).

Results: Attributes like the success of regeneration, the structure of seedlings by species and the recruitment of saplings were analysed with regards to ownership, forest communities and the aim of forest management. The results indicate poor incidence of regeneration especially of silver fir (more than $50 \%$ percent of field plots with no regeneration). Silver fir saplings (height $>1.3 \mathrm{~m}, \mathrm{dbh} \leq 10 \mathrm{~cm}$ ) are registered on $9 \%$ of plots, average number being only 165 per ha (all species together 2044 per ha). The estimated average share of the regenerated area is $16.3 \%$ of total forest area, contributed by $5.2 \%$ of conifers and $3.8 \%$ silver fir. A total of 14 tree species were recorded on regenerated areas, clearly dominated by broadleaves, especially beech (over $50 \%$ ).

Conclusions: Significant differences in regeneration attributes were proven by ANOVA between ownership categories, forest communities and habitat characteristics. In order to get better insight on the structure of regeneration, it is recommended to improve future assessment by establishing special sub-plots for measurement of seedlings by species.
\end{abstract}

Keywords: selection forest management, silver fir, European beech, regeneration structure, recruitment

\section{INTRODUCTION}

Stand regeneration is a basic task of forest management and therefore natural regeneration with minimal interventions presents a special challenge, as well as the aim of modern forest management planning [1].

Uneven-aged forest management including also selection management approach in circumstances of emphasised multi-functionality and ecological significance of forests on the global level forest science is recognized as the most acceptable management approach. Since the basic prerequisite for establishing and maintaining selection forest management is continuous stand regeneration through entire stand area, then stand regeneration assessment is more demanding in relation to even-aged management.

Numerous studies of intensity and models of canopy openings in terms of gap size and its enlarging [2], as well as the success of regeneration in selection forests have been published recently. Possibly, due to the complexity of stand regeneration estimations in beech-fir forests which 
include assessments of seed plants' abundance, such research in Croatia was mainly carried out on sporadic permanent sample plots or individual management units [3, 4]. Regeneration processes in beech-fir old-growth forests in Croatia and abroad were studied considerably more [5, 6]. The results of influential factors and relations with stand structures and regeneration success were also published, e.g. the impacts of stand opening models [2], light intensity [7], population of herbivores [8, 9] and fellings [10] on quality and abundance of silver fir seedlings.

Integrating research based on permanent sample plots and National Forest Inventory (NFI) data could provide a basis for the development of prediction models of stand regeneration in frame of stand growth simulators [11, 12]. Thereof, the existing stand growth simulators provide possibilities of research of stand openings (selection cut intensity) and their influences on stand regeneration [2].

In Croatia, stand-wise inventory has been conducted periodically every 10 years. However, the estimation of stand regeneration structure has not been included. On the other hand, the estimation of stand regeneration structure is included in almost all national inventories, especially in countries where national inventory has a long tradition [13]. Until now only the first national forest inventory in Croatia has been conducted, in which the assessments and information of forest regeneration are included [14].

It is clear that many factors influence stand regeneration and also that forest trees react by increased seed production in circumstances of stress. On the other hand, the abundance and survival of seedlings depend on ecosystem stability. In the context of climate changes, recent research on climate changes (e.g. the influence of air temperature increase or dry periods on the abundance and growth of seedlings) has special importance $[2,15]$. Climate changes can influence the appearance of several tree species in stand regeneration, namely tree species' alterations in stand structure. Climate change in specific areas is characterized by climatic extremes that do not have a clear trend in a short term. In such circumstances, the appearance of pioneer and wide-valent tree species that are adaptive to such conditions can be expected. Consequently, stand regeneration characteristics can be used as valuable indicators of ecosystem stability, the success of forest management in the past and of forest development in the future.

The aim of this paper is to obtain and analyse regeneration characteristics of beech and fir forests in Gorski kotar region, as well as to determine implications of stand regeneration on future forest management in the region, based on the data set obtained from national forest inventory field sample plots. The main assumption is that the abundance and structure of stand regeneration in beech and fir forests in Gorski kotar region during last decades would not sustain establishment and maintenance of selection management, particularly in the sense of maintenance of structural and inter-species relationships in the beech-fir forests. Additionally, significant differences between different site and stand factors and also the impact of management approaches (ownership) on stand regeneration can be expected. Since the success of regeneration directly influences future management activities, it is assumed that the adaptation of management model to current site and stand characteristics of the beechfir forests would be needed in the future.

\section{MATERIAL AND METHODS}

\section{Study Site}

The study site encompasses beech and fir forests in Gorski kotar region (Figure 1). Gorski kotar, known as the "Green heart of Croatia", spreads on $1273 \mathrm{~km}^{2}$ [16]. The region belongs to the continental carst area where forests grow on limestone-dolomite substrates (90\%) and partly on silicate substrates with basic soils (cambisols and leptosols). The dominant forest type is beech-fir forest community Omphalodo-Fagetum [17], while silver fir forests on silicate Blechno-Abietetum encompasses smaller part of forests. The altitude ranges between 350 and $1534 \mathrm{~m}$ above sea level. The studied area is characterized by continental climate with average annual temperature of $7.3^{\circ} \mathrm{C}$ and annual precipitation of $2275 \mathrm{~mm}$ (meteorological station Delnice). North-east and south-west aspects with many sunny sites are dominant, with inclination reaching above 20\% [16].

\section{Field Data}

Data on structure and characteristics of stand regeneration in Gorski kotar region were obtained from field measurements and assessments in the first national forest inventory conducted in the area during 2007. The procedures and methods of the inventory are described in Čavlović et al. [18]. The estimation of stand regeneration characteristics was based on the assessment of seedlings and saplings. The structure of seedlings up to $1.30 \mathrm{~m}$ height was estimated on a circular plot (radius $13 \mathrm{~m}$ ) with the assessment of 1) regenerated area (plot coverage with seedlings) in 10\% classes, 2) the origin of plants (stand establishment), 3) the share of tree species, 4) main tree species, 5) regeneration quality, 6) damage and the cause of damage and 7) the degree of damage. On a sub-plot with radius $2 \mathrm{~m}$ trees ranging from 0 to $10 \mathrm{~cm}$ dbh were measured according to tree species and diameter classes (0-3.99, 4-6.99, and 7-9.99 $\mathrm{cm}$ ) and the assessment of average tree heights of several tree species within several diameter class. Qualitative plot data on administrative categories, ownership, site and stand variables were also recorded and used in the analyses of stand regeneration.

\section{Data Analysis}

The database of plots according to regeneration state and structure, ownership, site and stand characteristics from sampled 313 plots was designed. Two indicator variables of regeneration were analysed: regenerated area (area covered by juvenile plants in \%) and the number of saplings (trees $\mathrm{dbh}<10 \mathrm{~cm}$ ). For a more clear presentation, species were grouped in categories (conifers and broadleaves). One-way analysis of variance (ANOVA) was used for testing differences of regenerated area and the number of trees between categories (ownership, forest type (community), canopy closure, soil depth, rockiness, aspect). In the case of significant statistical differences post - hoc LSD test was 


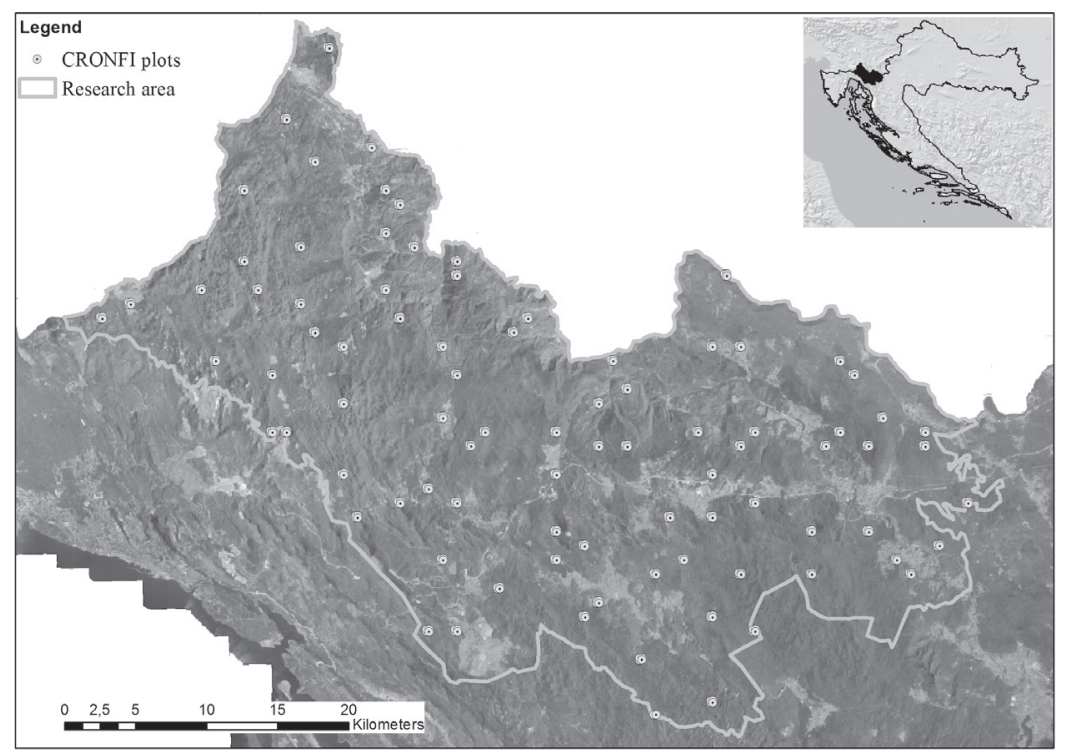

FIGURE 1. Study site area and the sample of field plots

used. All statistical analyses were performed with level of significance being 0.05 . The database was designed in EXCEL 2010, while the statistical analyses and the preparation of graphical presentation were performed in STATISTICA 11.1.

\section{RESULTS}

\section{Regenerated Area}

An average regenerated area of $16.6 \%$ was obtained. Silver fir contributes to the seedlings with less than one quarter (3.82\%), and by including Norway spruce conifers contribute with the share of $5 \%$. The remaining $11.6 \%$ is composed of broadleaved tree species with dominant share of European beech (8.8\%) followed by Norway maple (1.8\%), while seedlings of other broadleaved tree species in average cover less than $0.2 \%$ of the sample plot area (Table 1 ).

The number of saplings and young trees ( 0 to $10 \mathrm{~cm} \mathrm{dbh}$ ) amounted to 2044 per ha and can generally be considered sufficient for sustainable selection management. However, silver fir as the most important tree species in ecological and management sense, contributes with only 165 trees per ha. On the other hand, in the high share of other broadleaves (over 50\%) prevails rowan, a species which has no management importance in Gorski kotar region. This fact indicates regeneration problems in the studied forests in the long term, as well as caution in interpreting the importance of saplings and young trees as indicators of stand regeneration. As expected, the number of saplings and young trees is decreasing with the increase of diameter classes as a consequence of competition and tree growth processes.

The results of regenerated area according to six selected management-, site- and stand- characteristics of the studied beech and fir forests (ownership, forest type (community), canopy closure, soil depth, rockiness and aspect) are presented in Figure 2 and Table 2. The area regenerated by conifers was usually lower in relation to broadleaves, with exception of private forests where conifer seedlings cover in average almost $19 \%$ of sample plot. Forest type has shown

TABLE 1. Stand regeneration in Gorski kotar represented by average seedling coverage (by tree species) and the number of saplings per ha (by diameter classes and tree species).

\begin{tabular}{|c|c|c|c|c|c|}
\hline \multirow{2}{*}{ Stand regeneration } & \multicolumn{4}{|c|}{ Tree species } & \multirow{2}{*}{ Total } \\
\hline & Silver fir & Other conifers & E. beech & Other broadleaves & \\
\hline \multicolumn{6}{|c|}{ Average share of stand covered by seedlings up to $1.3 \mathrm{~m}$ height (\%) } \\
\hline & 3.82 & 1.34 & 8.86 & 2.56 & 16.60 \\
\hline \multicolumn{6}{|c|}{ Number of saplings $(0-10 \mathrm{~cm} \mathrm{dbh})$ per ha by diameter classes } \\
\hline $0-3.99 \mathrm{~cm}$ & 78 & 66 & 557 & 775 & 1476 \\
\hline $4-6.99 \mathrm{~cm}$ & 59 & 23 & 107 & 186 & 375 \\
\hline $7-9.99 \mathrm{~cm}$ & 28 & 18 & 59 & 89 & 194 \\
\hline Total & 165 & 107 & 723 & 1050 & 2044 \\
\hline
\end{tabular}


influence whereas conifer species have better regeneration success in forest communities with dominant share of silver fir and Norway spruce (coverage up to $10 \%$ ), unlike forest communities with dominant share of broadleaved tree species where the obtained average coverage of conifer seedlings is up to $5 \%$. The influence of crown coverage and aspect was shown as unclear, while soil depth showed influence on the abundance of broadleaved seedlings (Figure 2).

The results of one-way analyses of variance showed statistical significant differences of regenerated area according to: ownership for both conifers $(p=0.000)$ and broadleaves
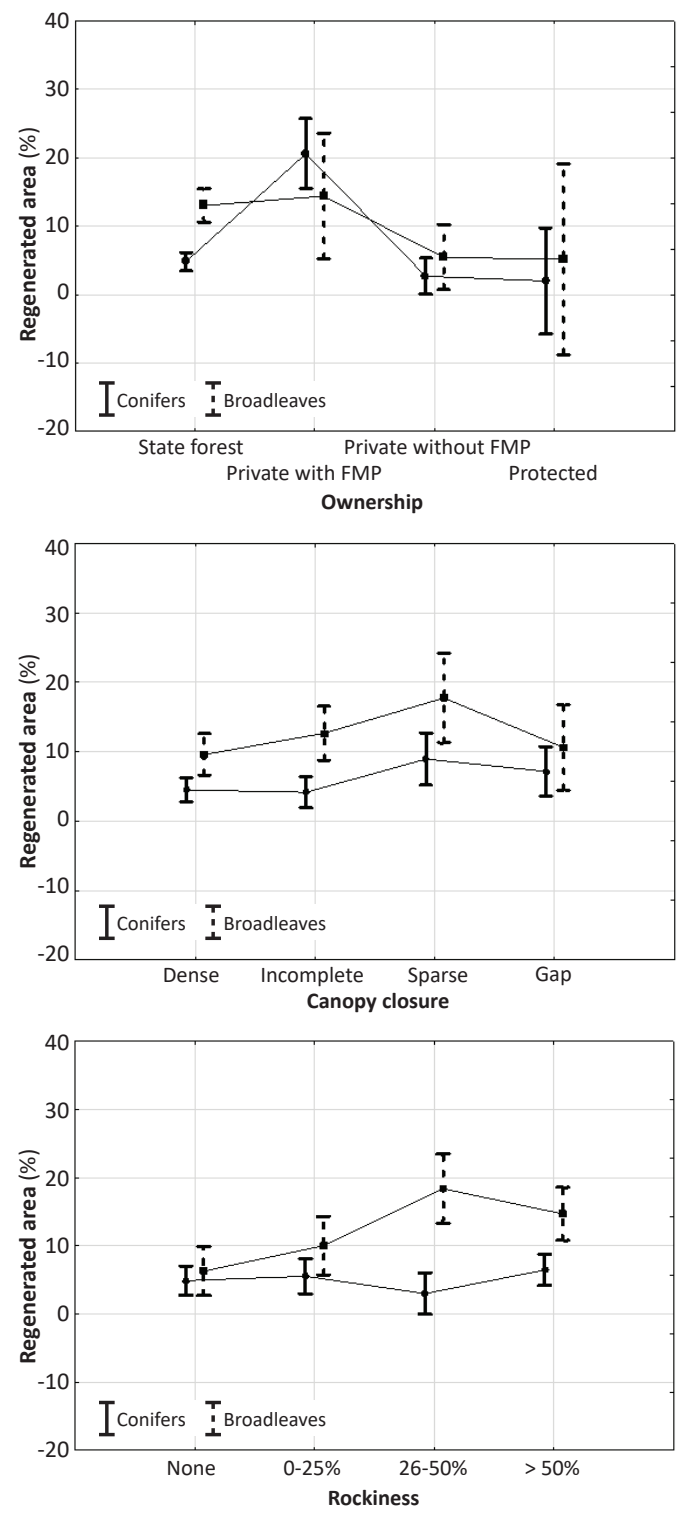

$(p=0.032)$, forest type (community) only for conifers $(p=0.000)$, soil depth only for broadleaves $(p=0.0013)$, rockiness for broadleaves $(p=0.000)$ and aspect for broadleaves $(p=0.020)$ (Table 2). The level of canopy closure has not shown to make significant difference neither for conifers nor for broadleaves.

The best regeneration of conifers is observed in private managed forests that are outstanding to other ownership categories (proven significantly different by LSD test, Table 2). For broadleaved seedlings, less differences with only significant difference between state forests and private unmanaged forests were obtained. Forests of Norway spruce and silver fir
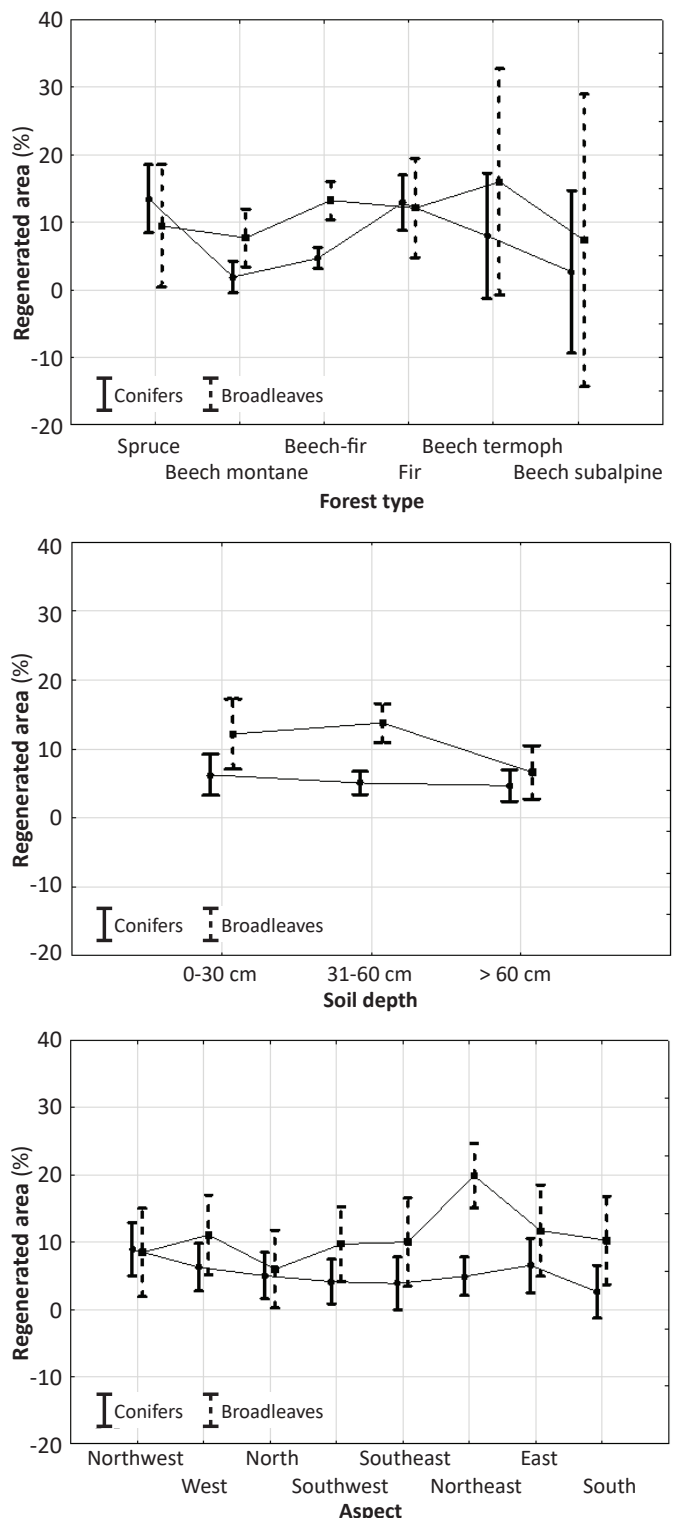

FIGURE 2. Regenerated area (\%) according to categories of management, stand and site variables. Vertical lines stand for $95 \%$ confidence intervals. 
TABLE 2. Descriptive statistics, ANOVA and post-hoc results for regenerated area by ownership, forest type, canopy closure, soil depth, rockiness and aspect.

\begin{tabular}{|c|c|c|c|c|c|c|c|c|c|}
\hline & & \multicolumn{8}{|c|}{ Regenerated area (\%) } \\
\hline & & \multicolumn{4}{|c|}{ Conifers } & \multicolumn{4}{|c|}{ Broadleaves } \\
\hline & $\mathrm{n}$ & $\begin{array}{l}\text { Arithmetic } \\
\text { mean }\end{array}$ & $\begin{array}{c}\text { Stand. } \\
\text { deviation }\end{array}$ & $\begin{array}{l}\text { ANOVA } \\
p \text { value }\end{array}$ & $\begin{array}{l}\text { Post } \\
\text { hoc }\end{array}$ & $\begin{array}{c}\text { Arithmetic } \\
\text { mean }\end{array}$ & $\begin{array}{c}\text { Stand. } \\
\text { deviation }\end{array}$ & $\begin{array}{l}\text { ANOVA } \\
p \text { value }\end{array}$ & $\begin{array}{l}\text { Post } \\
\text { hoc }\end{array}$ \\
\hline \multicolumn{10}{|l|}{ Ownership } \\
\hline State forests & 228 & 4.83 & 9.47 & \multirow{5}{*}{$0.000^{*}$} & a & 11.46 & 18.90 & \multirow{5}{*}{$0.032 *$} & a \\
\hline Private with FMP & 16 & 20.59 & 22.96 & & $\mathrm{~b}$ & 13.02 & 20.19 & & $a b$ \\
\hline Private without FMP & 60 & 2.70 & 8.99 & & a & 14.41 & 15.24 & & $b$ \\
\hline Protected & 7 & 2.00 & 3.83 & & a & 5.47 & 13.86 & & $a b$ \\
\hline Total & 311 & 5.17 & 10.98 & & & 11.46 & 18.90 & & \\
\hline \multicolumn{10}{|l|}{ Forest type } \\
\hline Spruce & 17 & 13.47 & 17.19 & \multirow{7}{*}{$0.000^{*}$} & a & 9.47 & 15.06 & \multirow{7}{*}{0.399} & - \\
\hline Beech montane & 76 & 1.90 & 6.20 & & $b$ & 7.70 & 15.58 & & - \\
\hline Beech - fir & 178 & 4.68 & 8.74 & & $b$ & 13.24 & 20.36 & & - \\
\hline Fir & 26 & 12.88 & 20.93 & & a & 12.12 & 21.02 & & - \\
\hline Beech thermoph. & 5 & 8.00 & 17.89 & & $a b$ & 16.00 & 21.91 & & - \\
\hline Beech subalpine & 3 & 2.67 & 4.62 & & $a b$ & 7.33 & 6.43 & & - \\
\hline Total & 305 & 5.21 & 11.04 & & & 11.54 & 19.03 & & \\
\hline \multicolumn{10}{|l|}{ Canopy closure } \\
\hline Dense & 152 & 4.49 & 11.40 & \multirow{5}{*}{0.091} & - & 9.59 & 17.68 & \multirow{5}{*}{0.134} & - \\
\hline Incomplete & 91 & 4.16 & 8.77 & & - & 12.65 & 19.94 & & - \\
\hline Sparse & 33 & 8.94 & 12.87 & & - & 17.73 & 21.82 & & - \\
\hline Gap & 36 & 7.17 & 11.67 & & - & 10.61 & 17.32 & & - \\
\hline Total & 312 & 5.17 & 10.97 & & & 11.46 & 18.87 & & \\
\hline \multicolumn{10}{|l|}{ Soil depth } \\
\hline $0-30 \mathrm{~cm}$ & 52 & 6.27 & 9.32 & \multirow{4}{*}{0.707} & - & 12.19 & 18.04 & \multirow{4}{*}{$0.013^{*}$} & $a b$ \\
\hline $31-60 \mathrm{~cm}$ & 170 & 5.09 & 11.74 & & - & 13.79 & 19.75 & & $\mathrm{a}$ \\
\hline$>60 \mathrm{~cm}$ & 90 & 4.70 & 10.38 & & - & 6.63 & 16.80 & & $b$ \\
\hline Total & 312 & 5.17 & 10.97 & & & 11.46 & 18.87 & & \\
\hline \multicolumn{10}{|l|}{ Rockiness } \\
\hline none & 102 & 4.90 & 11.50 & \multirow{5}{*}{0.341} & - & 6.28 & 15.34 & \multirow{5}{*}{$0.000 *$} & $\mathrm{a}$ \\
\hline $0-25 \%$ & 72 & 5.54 & 11.45 & & - & 10.01 & 15.74 & & ac \\
\hline $26-50 \%$ & 51 & 3.00 & 6.12 & & - & 18.37 & 24.91 & & $b$ \\
\hline$>50 \%$ & 87 & 6.47 & 12.03 & & - & 14.68 & 19.32 & & bc \\
\hline Total & 312 & 5.17 & 10.97 & & & 11.46 & 18.87 & & \\
\hline \multicolumn{10}{|l|}{ Aspect } \\
\hline Northwest & 31 & 8.95 & 16.52 & \multirow{9}{*}{0.445} & - & 8.47 & 17.55 & \multirow{9}{*}{$0.020^{*}$} & $\mathrm{a}$ \\
\hline West & 38 & 6.28 & 10.21 & & - & 11.09 & 15.00 & & $\mathrm{a}$ \\
\hline North & 40 & 5.01 & 13.29 & & - & 5.99 & 9.44 & & $\mathrm{a}$ \\
\hline Southwest & 44 & 4.15 & 6.95 & & - & 9.72 & 19.02 & & $a$ \\
\hline Southeast & 31 & 3.85 & 10.19 & & - & 10.02 & 17.55 & & $a$ \\
\hline Northeast & 58 & 4.93 & 10.95 & & - & 19.90 & 26.36 & & $b$ \\
\hline East & 29 & 6.55 & 11.23 & & - & 11.72 & 16.25 & & $a b$ \\
\hline South & 31 & 2.63 & 7.78 & & - & 10.27 & 17.15 & & $\mathrm{a}$ \\
\hline Total & 302 & 5.22 & 11.11 & & & 11.50 & 18.90 & & \\
\hline
\end{tabular}

*statistically significant 
have significant difference in relation to beech and beech fir forests when abundance of conifer seedlings is considered. Significant differences between categories of rockiness, soil depth and aspect are proven only for broadleaved seedlings as shown in Table 2.

\section{Number of Saplings}

The number of saplings (trees with $\mathrm{dbh}<10 \mathrm{~cm}$ ) according to the abovementioned categories is presented in Table 3 and Figure 3. Alike regenerated area, the abundance of saplings (number per ha) indicates outstanding difficulties in stand regeneration by conifers, namely silver fir. Almost none of the six characteristics (factors) of the studied forests have shown significant influence on the abundance (appearance) of silver fir saplings. Some differences indicate the influence of forest communities. Thus, in thermophile beech forests there is the highest number of silver fir saplings. However, in such site conditions small silver firs are rarely saplings, but usually these are grown and mature trees. Differences in the number of broadleaved saplings are more expressed. The total number of saplings per hectare seems sufficient, but the fact that rowan contributed to almost one half indicates a low stand regeneration potential. Soil depth (and the resulting site quality) expectedly showed positive influence on the abundance of broadleaved saplings (Figure 3).

One-way analyses of variance showed statistically significant differences of small trees abundance only for soil variables (soil depth, rockiness) as follows: soil depth for broadleaves $(p=0.00001)$ and for all species $(p=0.00003)$; and rockiness for conifers $(p=0.03504)$, for broadleaves $(p=0.02572)$ and for all species $(p=0.00427)$ (Table 3$)$.

According to post-hoc LSD test for broadleaved and for all tree species small trees, significant differences between the deepest soil and other categories of shallower soil were proven. Similarly, the first category of rockiness (without rockiness) has significant difference in relation to other categories of rockiness for all groups of tree species (conifers, broadleaved, all species) as shown in Table 3.

\section{DISCUSSION}

The level and structure of forest regeneration is of special concern for forest management planning. Forest management in Croatia is predominantly based on natural regeneration, whereas in uneven-aged beech-fir stands it is being exclusively used.

However, due to various causes, regeneration in beech-fir selection forests is found to be insufficient. It can be tracked in diameter structure from stand-wise inventories, sporadic research on permanent plots in managed forests $[19,20]$ and old growth forests [21], and also from the results of the first national forest inventory [14].

Systematic field measurements and assessments performed within national forest inventory on 313 sample plots enabled sound analysis of regeneration in beech and fir forests in Gorski kotar. Spatial stratification according to different criteria helped to track possible influences on regeneration. Specific multilayer structure of selection forest complicates the assessment and measurement of regeneration and juvenile trees and especially the interpretation of the results $[7,22]$. The methodology of measurement used is the same for all forest types and regions, with regeneration being assessed by measurement of trees ranging from $0-10 \mathrm{~cm} \mathrm{dbh}$ and ocular assessment of regenerated area. While saplings (trees of $0-10 \mathrm{~cm} \mathrm{dbh}$ ) were measured on a small plot ( $\mathrm{r}=2 \mathrm{~m})$, regenerated area (seedlings) was assessed on a rather large one $(r=13 \mathrm{~m})$. The assessment of the regenerated area was therefore time-consuming due to the size of the plot, and it also resulted with rough data (estimate of the area instead of density) with questionable consistency between field crews (subjectivity of assessment). Possible improvement in the next forest inventory would be introducing a small subplot for counting and measurement of seedlings (up to $130 \mathrm{~cm}$ height). This approach would improve data collection and make data more precise and less subjective. Categorical variables would however still be necessary for assessing the origin, quality and damage of seedlings.

The acquired data are, however, valuable for the inspection of natural regeneration in selection beech-fir forests. Since silver fir is the fundamental species for these forests, its regeneration is crucial for their survival. Average regenerated area of silver fir was assessed 3.82\%, thus clearly indicating problems with natural regeneration. By adding spruce, total conifer regenerated area is about $5 \%$, whereas broadleaved saplings cover about $11 \%$, beech being dominant (about 9\%) and sycamore maple following with less than $2 \%$. Other species are sporadically present with regenerated areas less than $0.2 \%$.

The presented results on structure of regeneration clearly indicate evident change in uneven-aged beech-fir forests in Gorski kotar region. The present stage of regeneration will expectedly lead to a decreasing share of conifers (especially fir) in favour of the increasing share of beech and other broadleaves. Possible causes of that change are as following: a) natural substitution of species, b) recovery of beech that was reduced by past management, c) alteration of habitat conditions as a result of climate change, d) management activities that favour broadleaves. Most likely all mentioned causes occur simultaneously and interact with different intensities on each area.

These forests are traditionally characterized by low intensity selection harvests and natural regeneration without any seeding or planting. The results of the inventory confirm this fact - the recorded seedlings are all of natural and mostly generative (97.4\% plots) origin. However, due to the present level of regeneration and habitat conditions, it is questionable whether future management can sustainably rely exclusively on natural regeneration. This is specially emphasized in the case of silver fir which is a species of fundamental importance in the selection management. An insufficient level of natural regeneration leads inevitably to the collection and production of seeds and seedlings of silver fir, and also requires planning the planting procedures. At the same time adequate management activities should raise the level and success of natural regeneration $[10,19,20]$ wherever and as much as it is possible.

The quality of saplings heavily relies on ecological conditions, especially on the intensity of light. Since this variable was assessed for all species together, detailed analysis 

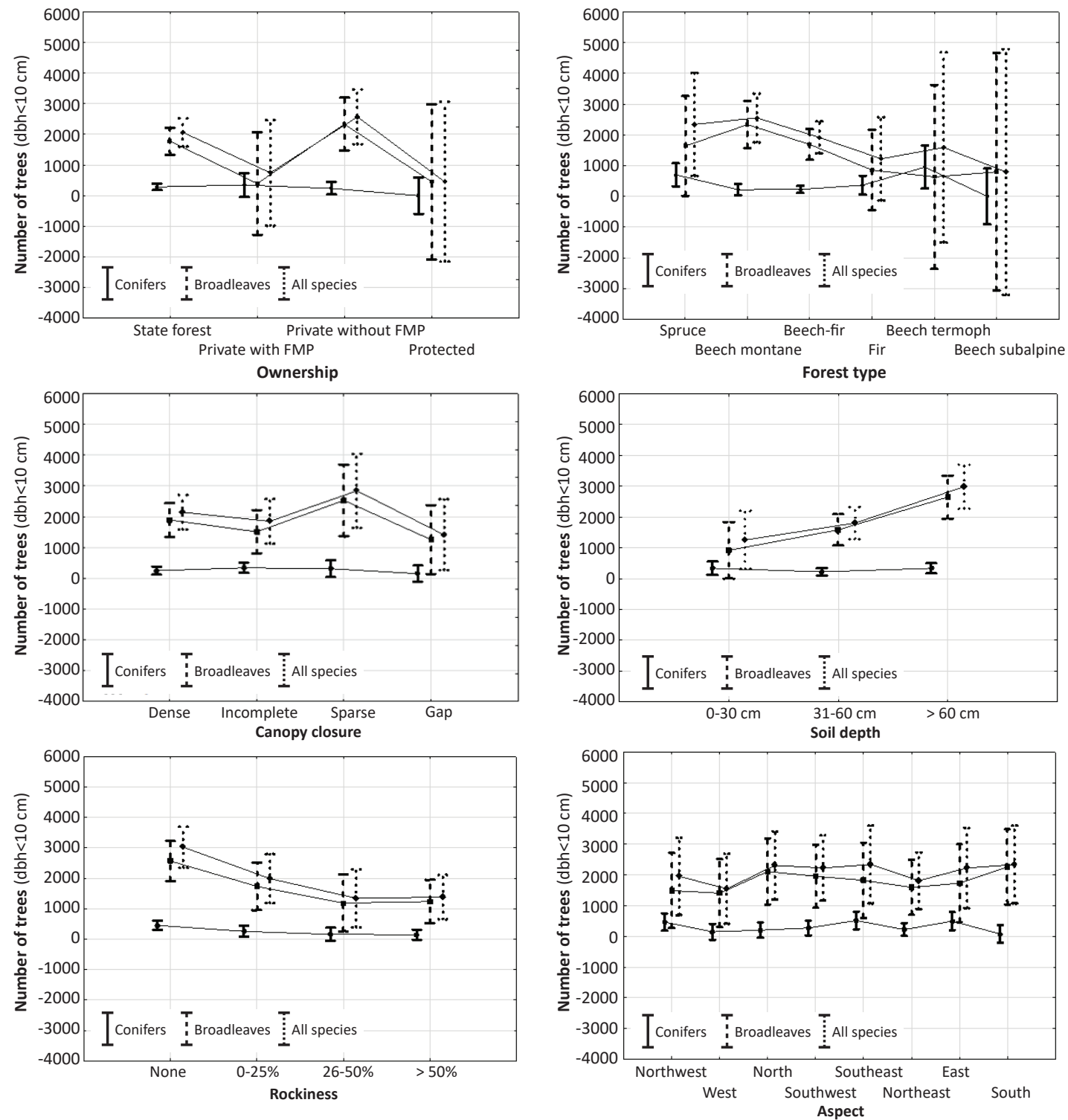

FIGURE 3. The number of saplings $(\mathrm{dbh}<10 \mathrm{~cm})$ according to categories of management, stand and site variables. Vertical lines stand for $95 \%$ confidence intervals.

is not possible. According to the results, the quality of saplings was assigned as very good and good on $90 \%$ of plots. It can be presumed that the results for silver fir would be somewhat different if assessed separately. It can generally be concluded that saplings are of good quality and survive when they appear, thus indicating favourable habitat conditions. On the other hand, management activities do not ensure enough level of sapling occurrence on most areas [20, 23]. Future management influence is, however, supposed to change due to significant change in selection management approach recorded in the past decade [24].
Researched beech-fir stands can be considered to be part of a balanced ecosystem since seedlings were not damaged on $75 \%$ of plots. On the rest of the plots, the most common causes of damage were insects and sporadically diseases and herbivores. It is even a more important finding since herbivores are considered to be a significant threat to regeneration in Middle European beech-fir forests [8, 9, 25]. This result can possibly be addressed to successful game management and also to presence of natural predators (lynx, wolf, bear). Other reasons can be close to nature forest management that enables abundance of available feed [26]. 
TABLE 3. Descriptive statistics, ANOVA and post-hoc results for the number of saplings per ha by ownership, forest type, canopy closure, soil depth, rockiness and aspect.

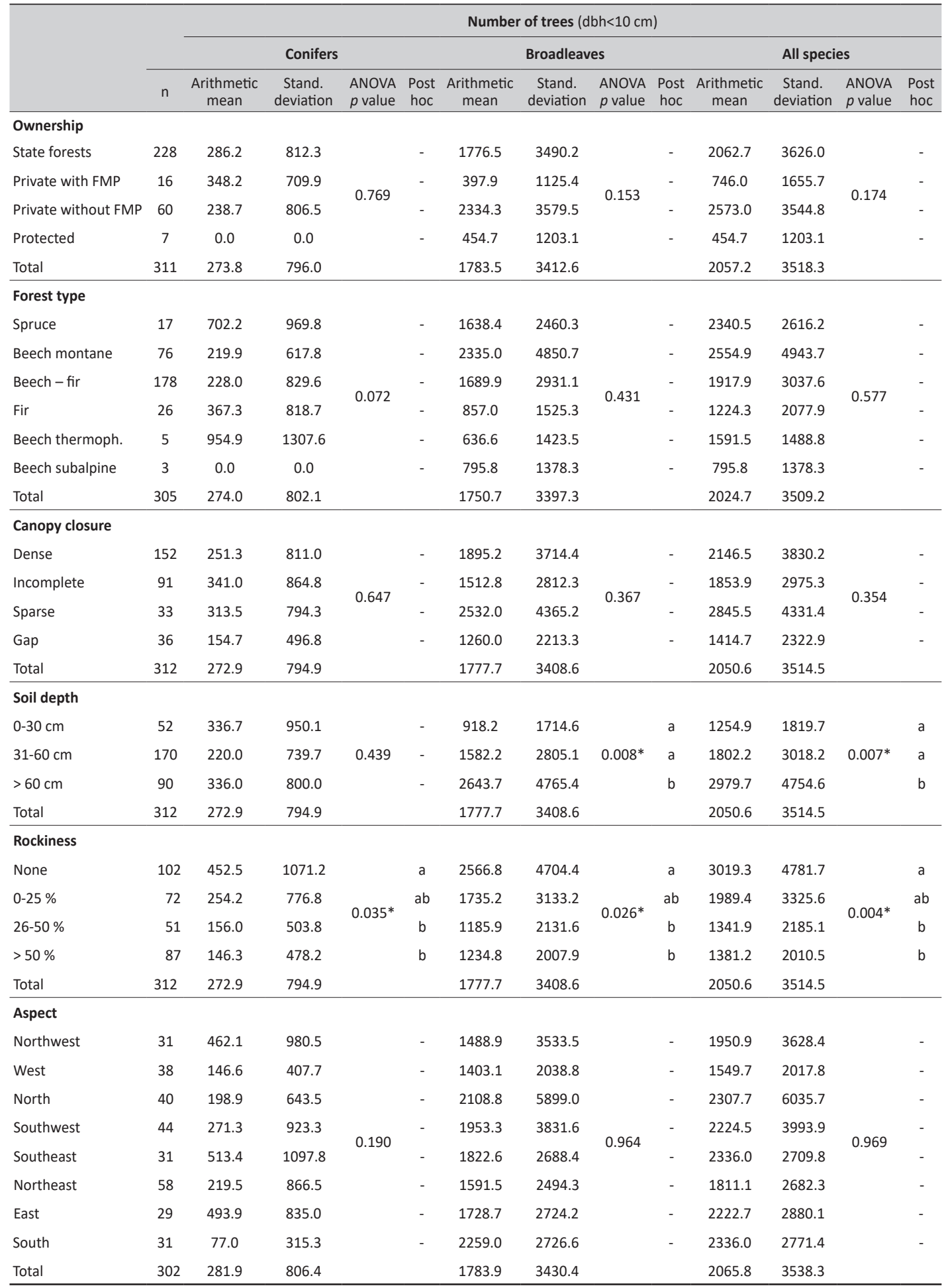

*statistically significant 
The abundance of saplings indicates successful regeneration during the past decades. However, in beechfir stands, depending on the site characteristics and stand attributes, trees can be held down for years without reaching large dimensions. This is in particular characteristic of silver fir that is proven to survive more than 50 years in shade without significant growth [3].

A total number of 2044 trees $\cdot \mathrm{ha}^{-1}$ of $\mathrm{dbh}<10 \mathrm{~cm}$ seems adequate to assure sufficient recruitment of saplings. Along with standard management activities it should consequently maintain sustainable uneven-aged selection stand structure.

However, analysis by species reveals a somewhat different picture - the number of thin silver fir trees is very low and it clearly indicates future significant decrease of fir in beech-fir forests. A great share of thin trees are side species - mostly rowan that hardly exceeds $\mathrm{dbh} 10 \mathrm{~cm}$ in given conditions. Also in stands on higher altitudes and unfavourable sites, fir and beech trees under $10 \mathrm{~cm}$ dbh cannot all be addressed as a regeneration since it is medium size that trees can reach in such conditions. Therefore the number of trees $\mathrm{dbh}<10 \mathrm{~cm}$ should be interpreted with caution, since just a small share of them represents regeneration, thus consequently pointing on the problem with regeneration in the past. Unfortunately, the quality and damage of saplings were not assessed - such results would better indicate the real state of regeneration and reveal the problems with the transition of saplings (recruitment). Hence the assessment of quality and damage of saplings should be integrated in the following cycles of NFI.

The present state of forests, including intensity and structure of regeneration, is a result of management activities in the past. With assumption that type of ownership also presents specific the type of forest management [27], we analyzed regeneration structure by ownership. Significantly higher regenerated area in private than in state forests indicates inadequate management model in state forests (Figure 2). This is specially emphasized in the case of conifers where regenerated area in private forests is four times greater than in the state forests. High growing stock with great share of conifers and almost even-aged structure is obviously not favourable for fir regeneration, as already reported in previous studies $[19,20,23]$. It is also interesting that thin broadleaved trees are significantly more abundant in state forests but also in private non-managed forests (without management plans), than in private forests managed according to management plans. Those are mostly rowan, maple and beech trees that remain in suppressed layer for years. Such trees have ecological role, but they do not influence future stand structure in managed stands. In the protected area (National Park Risnjak) regeneration is almost absent, especially for fir. It can be attributed to natural dynamics of forests where mature old single layer stands will slowly come to natural regeneration after natural opening of gaps.

The differences in regeneration between forest types (phytocenoses) are clearly demonstrated - conifers successfully regenerate on optimal sites, i.e. on acidophilic soils upon silicate bedrock. In other forest types conifers are significantly less present. Broadleaves regenerate equally well in all plant communities represented on the research area. The number of saplings trees is surprisingly the highest in thermophile beech, which can be attributed to unfavourable site conditions where fir trees can remain stagnant for entire life, and maybe to a small sample size.
Present canopy closure has obviously higher impact on regeneration than on abundance of thin trees. Significantly higher regenerated area is evident in stands with sparse canopy closure in relation to both complete closure and gaps. It suggests that adequate management activities have to be taken to stimulate regeneration - moderate opening of stands will induce regeneration of (mostly) broadleaves. With consequent care of saplings and possible introduction of fir seedlings, stable mixed uneven-aged stands could be achieved.

Ecological factors like soil depth, rockiness and aspect have significant impact on regeneration. It is interesting that plots with deepest soil and least rockiness do not have highest abundance of seedlings, indicating that these are not crucial requirements for plants to grow in the first phase. Saplings are, however, most abundant on those plots, where deepness and quality of soil play an important role, also substituting the lack of light. It is also likely that on shallow and stony soil trees with up to $10 \mathrm{~cm}$ dbh form a final and continuous stage of stand development. Although there are differences in regenerated area according to aspect (especially for broadleaves), they cannot be reliably confirmed. Conifers are shown to prefer east and west oriented sites.

Possible other influences, e.g. of climate change, have not been covered in this research. Also, the complex model of individual and mutual influence of stand and site characteristics would surely make a clearer insight on the success of regeneration, and point out the causes of the present state. However, the presented results - poor incidence of seedlings (trees under $1.3 \mathrm{~m}$ ) and sapling conifer trees - indicate extremely poor regeneration in selection forests, silver fir in particular. Therefore management planning and management activities should be directed in a way to promote fir regeneration and the survival of existing seedlings. It could imply additional involvement in regeneration by the introduction of seeds and seedlings. On the other hand, regeneration of other species (dominantly beech) indicates naturalness and biodiversity of beech-fir forests which should be fostered as much as possible.

\section{CONCLUSION}

The level and structure of regeneration in beechfir forests of Gorski kotar region, based on the results of $\mathrm{NFI}$, is characterized by low regeneration of silver fir, and significantly better success of broadleaves. Common beech regenerates well on the whole researched area. Significant share of other broadleaves (sycamore maple, rowan etc.) indicates well preserved naturalness of forests. Some differences in regeneration structure can be found between forest communities and site conditions - acidophilic sites on silicate bedrock are favoured by conifers, while thermophile and more extreme sites are dominated by beech.

The influence of various owners through different management concepts has also been demonstrated. It can be generally concluded that management models that establish more mixed forests with higher size diversity and lower growing stock enable better regeneration. Management planning should take that into account and adjust future activities into that direction. It will surely help fir regeneration to some extent, while maintaining share of fir over $50 \%$ would require aided regeneration by additional 
seedlings. It is feasible in the framework of close to nature forest management that it will maintain naturalness and biodiversity of Dinaric beech-fir forests in the long term.

The importance of regeneration as an indicator of both ecosystem stability and the success of forest management requires additional concern in forest inventory. The metho- dology of measurement and assessment should be improved with special sub-plots for more detailed measurement of seedlings. More reliable and more detailed results on regeneration would lead to better projection of development of forest resources, enabling also more active adaptation of future management activities.

\section{REFERENCES}

1. MEA 2005 Millennium Ecosystem Assessment, Ecosystems and Human Well-Being: Synthesis. Island Press, Washington, DC, USA, 137 p. URL: http://www.unep.org/ maweb/documents/document.356.aspx.pdf (25 July 2016)

2. LAFOND V, LAGARRIGUES G, CORDONNIER T, COURBAUD B 2014 Uneven-aged management options to promote forest resilience for climate change adaptation: effects of group selection and harvesting intensity. Ann For Sci 71 (2): 173-186. DOI: https://doi.org/10.1007/s13595-013-0291-y

3. MATIĆ S 1983 The impact of ecological and structural factors on natural regeneration of fir and beech selection forests in Gorski kotar. Glas sum pok 21: 223-401

4. ANIĆ I, PERKOVIĆ M, MIKAC S 2009 Natural regeneration of silver fir (Abies alba Mill.) along the edge of the Zagreb Rijeka motorway. Glas sum pok 43: 37-49

5. ROZENBERGAR D, MIKAC S, ANIĆ I, DIACI J 2007 Gap regeneration patterns in relationship to light heterogeneity in two old-growth beech-fir forest reserves in South East Europe. Forestry 80 (4): 431-443. DOI: https://doi. org/10.1093/forestry/cpm037

6. ANIĆ I, MIKAC S 2008 Structure, texture and regeneration of Dinaric beech-fir virgin forests of Čorkova uvala. Sumar list 132 (11-12): 505-515

7. DOBROWOLSKA D, VEBLEN TT 2008 Treefall-gap structure and regeneration in mixed Abies alba stands in central Poland. Forest Ecol Manag 255(8-9): 3469-3476. DOI: https://doi.org/10.1016/i.foreco.2008.02.025

8. KLOPCIC M, JERINA, K BONCINA A 2010 Long-term changes of structure and tree species composition in Dinaric uneven-aged forests: are red deer an important factor? Eur J For Res 129 (3): 277-288. DOI: https://doi.org/10.1007/ s10342-009-0325-Z

9. VACEK Z, VACEK S, BILEK L, KRAL J, REMES J, BULUSEK D, KRALICEK I 2014 Ungulate Impact on Natural Regeneration in Spruce-Beech-Fir Stands in Cerny dul Nature Reserve in the Orlicke Hory Mountains, Case Study from Central Sudetes. Forests 5 (11): 2929-2946. DOI: https://doi. org/10.3390/f5112929

10. OLSON M, MEYER SR, WAGNER RG, SEYMOUR 2014 Commercial thinning stimulates natural regeneration in spruce-fir stands. Can Jour For Res 44 (3): 173-181. DOI: https://doi.org/10.1139/cjfr-2013-0227

11. HASENAUER H, KINDERMANN G 2006 Modelling Regeneration in Even and Uneven-Aged Mixed Species Forests. In: Hasenauer $\mathrm{H}(e d)$ Sustainable Forest Management. Springer, Berlin Heidelberg, Germany, pp 167-193. DOI: https://doi.org/10.1007/3-540-31304-4 13

12. BLANCO J, WELHAM C, KIMMINS JP, MAILLY D 2009 Guidelines for modelling natural regeneration in boreal forests. Forest Chron 85 (3): 427-439. DOI: https://doi. org/10.5558/tfc85427-3

13. TOMPPO E, GSCHWANTNER T, LAWRENCE M, MCROBERTS ER 2010 National Forest Inventories: Pathways for Common Reporting. Springer, Dordrecht, Netherlands, 609 p. DOI: https://doi.org/10.1007/978-90-481-3233-1

14. ČAVLOVIĆ J 2010 First National Forest Inventory in Republic of Croatia (in Croatian). Ministry of regional development and forestry \& Faculty of Forestry, Zagreb, Croatia, $300 p$
15. KLOPČIČ M, BONČINA A 2011 Stand dynamics of silver fir (Abies alba Mill.)-European beech (Fagus sylvatica L.) forests during the past century: a decline of silver fir? Forestry 87 (1): 71-84. DOI: https://doi.org/10.1093/ forestry/cpr011

16. KLEPAC D 1997 Iz šumarske povijesti Gorskoga kotara u sadašnjost (in Croatian). Hrvatske šume, Zagreb, Croatia, $237 \mathrm{p}$

17. MARINČEK L, MUČINA L, ŽUPANČIČ $M$, POLDINI L, DAKSKOBLER I, ACCETTO M 1992 Nomenklatorische Revision der illyrischen Buchenwälder (Verband AremonioFagion) [in German]. Stud Geobot 12: 121-135

18. ČAVLOVIĆ J, BOŽIĆ M, TESLAK K, VEDRIŠ M 2016 Croatia. In: Vidal C, Alberdi I, Hernández L, Redmond JJ (eds) Forest National Inventories: Assessment of Wood Availability and Use. Springer International Publishing, Switzerland. DOI: https://doi.org/10.1007/978-3-319-44015-6 15

19. ANIĆ I, MIKAC S, ORŠANIĆ M, DRVODELIĆ D 2006 Structural relations between virgin and management beech-fir stands (Omphalodo-Fagetum Marincek et al. 1992). Period biol 108 (6): 663-669

20. ČAVLOVIĆ J, BOŽIĆ M, BONČINA A 2006 Stand structure of an uneven-aged fir-beech forest with an irregular diameter structure: modeling the development of the Belevine forest, Croatia. Eur J For Res 125 (4): 325-333. DOI: https:// doi.org/10.1007/s10342-006-0120-z

21. DIACI J, ROZENBERGAR D, ANIC I, MIKAC S, SANIGA M, KUCBEL S, VISNJIC C, BALLIAN D 2011 Structural dynamics and synchronous silver fir decline in mixed old-growth mountain forests in Eastern and Southeastern Europe. Forestry 84 (5): 479-491. DOI: https://doi.org/10.1093/ forestry/cpr030

22. HESSENMÖLLER D, ELSENHANS AS, SCHULZE ED 2013 Sampling forest tree regeneration with a transect approach. Ann For Res 56 (1): 3-14

23. MATIĆ S, ORŠANIĆ M, ANIĆ I 1996 Some features and problems concerning silver fir (Abies alba Mill.) in Croatia (in Croatian with English summary). Sumar list 120 (3-4): 91-99

24. ČAVLOVIĆ J, BONČINA A, BOŽIĆ M, GORŠIĆ E, SIMONČIĆ T, TESLAK K 2015 Depression and growth recovery of silver fir in uneven-aged Dinaric forests in Croatia from 1901 to 2001. Forestry 88 (5): 586-598. DOI: https://doi. org/10.1093/forestry/cpv026

25. ROZMAN A, DIACI J, BATIČ F 2013 Functional analysis of vegetation on alpine treeline ecotone in the Julian and Kamnik-Savinja Alps in Slovenia. Eur J For Res 132 (4): 579591. DOI: https://doi.org/10.1007/s10342-013-0691-4

26. KRAPINEC K, MAJNARIĆ D, JOVANOVIĆ D, KOVAČ I, MEDARIĆ | 2011 Initial results of research into brown bear timber damage (Ursus arctos) in silver fir (Abies alba) forests in Croatia (in Croatian with English summary). Croat J For Eng 32 (1): 259-269.

27. BOŽıĆ M 2002 Management models applied to fir forests in Gorski kotar. Glas sum pok 38: 89-137 